\title{
Prediktor Penyakit Kardiovaskular pada Anak Obes Usia Sekolah Dasar di Kotamadya Surakarta
}

\author{
Sri Martuti, Endang D. Lestari, B. Soebagyo \\ Bagian Ilmu Kesehatan Anak Fakultas Kedokteran Universitas Sebelas Maret/RSUD Dr. Moewardi \\ Surakarta
}

Latar belakang. Lingkar pinggang atas seringkali dihubungkan dengan obesitas sentral yang berisiko tinggi terhadap penyakit kardiovaskular

Tujuan. Untuk mengetahui prevalensi abnormalitas kardiovaskular dan prediktor faktor-faktor risiko penyakit kardiovaskular di antara anak-anak obes.

Metode. Penelitian cross sectional dilaksanakan dari Januari sampai Februari 2005. Duapuluh persen dari SD di setiap kecamatan dipilih secara acak. Semua anak obes diikutsertakan dalam penelitian setelah didapatkan izin dari orangtua. Data dianalisa dengan SPSS 10.05 for windows. Odds ratio (OR) untuk faktor-faktor risiko kardiovaskular seperti tekanan darah sistolik dan diastolik yang tinggi, kadar kolesterol total, HDL, LDL, dan trigliserida yang abnormal dibandingkan antara kelompok yang memiliki lingkar lengan atas kecil dan lingkar lengan atas besar $(77,5 \mathrm{~cm})$. Analisa multivariat dilakukan untuk mengontrol faktor lain.

Hasil. Diantara anak-anak yang obes, 45,5\% menderita hiper trigliserida. Analisa univariat menunjukkan bahwa OR untuk LDL kolesterol yang abnormal, tekanan darah sistolik yang tinggi, tekanan darah diastolik yang tinggi masing-masing adalah 1,6 (95\% CI: 0,6-4,5); 4,7 (95\%CI: 0,5-41,8) dan 1,9 (95\% CI: $0,7-5,6)$. Odds ratio untuk lingkar lengan atas $(77,5 \mathrm{~cm})$ terhadap tekanan darah diastolik yang tinggi adalah 4,4 (95\% CI: 1,1-17,7); terhadap tekanan darah sistolik yang tinggi adalah 3,7 (95\% CI: 0,4-38,5); terhadap kadar kolesterol LDL abnormal adalah 1,7 (95\%CI: 0,4-6,5). Odds ratio untuk kadar kolesterol total, HDL dan trigliserida yang abnormal adalah 1,3 (95\% CI: 0,4-6,5); 1,1 (95\% CI: 0,4-3,2) and 1,2 (95\% CI: 0,5-3,1).

Kesimpulan. Prevalensi hipertrigliserida diantara anak obes $45 \%$. Lingkar pinggang atas 77,5 cm harus dipertimbangkan sebagai prediktor faktor risiko penyakit kardiovaskular. (Sari Pediatri 2008;10(1):18-23).

Kata Kunci: lingkar pinggang, faktor risiko, kardiovaskular

\footnotetext{
Alamat Korespondensi:

Endang Dewi Lestari, Dr.,Sp.A. Staf UPF. Anak. Bag.IKA RSUD

Dr. Moewardi Jl. Kol Sutarto 132 Solo Jawa Tengah. Telp. 0271- 666866
} 
Sri Martuti dkk: Prediktor Penyakit Kardiovaskular pada Anak Obes Usia Sekolah Dasar di Kotamadya Surakarta

$\mathrm{P}$ revalensi obesitas meningkat hingga mencapai tingkat epidemi di negara maju dan negara berkembang. ${ }^{1,2}$ Prevalensi obesitas balita di Indonesia menurut SUSENAS menunjukkan peningkatan di perkotaan maupun di pedesaan. Pada tahun 1989 di perkotaan didapatkan 4,6\% laki-laki dan 5,9\% perempuan. Tahun 1992 didapatkan 6,3\% laki-laki dan 8\% perempuan. Sedangkan tahun 1995 prevalensi obesitas di 27 propinsi adalah 4,6\%. Kasus obesitas di Departemen Ilmu Kesehatan Anak RS Cipto Mangunkusumo setiap tahun menunjukkan kenaikan dari 5 kasus tahun 1980 menjadi 22 kasus pada tahun 1988 dan 14 kasus pada 6 bulan pertama tahun $1995 .^{3}$

Indeks Masa Tubuh (IMT) merupakan cara yang termudah untuk memperkirakan obesitas dan berkorelasi tinggi dengan massa lemak tubuh. Petanda komplikasi obesitas seperti tekanan darah, lipid darah dan lipoprotein darah juga berkorelasi dengan IMT. 4,5 Kelemahan penggunaan IMT adalah penghitungannya tidak menunjukkan variasi distribusi lemak yang secara alamiah berbeda antar individu dan populasi. ${ }^{6}$ Beberapa penelitian pada orang dewasa mendapatkan bahwa distribusi lemak tubuh merupakan prediktor yang lebih baik dari IMT untuk faktor risiko, penyakit dan mortalitas. Peningkatan jaringan lemak pinggang dan visceral pada penderita obesitas dewasa mempunyai hubungan yang kuat dengan risiko penyakit kardiovaskular dan metabolik dan berbagai penyakit kronis. ${ }^{6,7}$

Metode yang akurat untuk menentukan distribusi lemak tubuh meliputi computer tomografi dan magnetic resonance imaging (MRI). Pada studi populasi yang besar, metode ini kurang sesuai karena mahal dan risiko terpapar radiasi. ${ }^{7}$ Lingkar pinggang merupakan pengukuran jaringan pinggang yang mudah, murah dan sangat berguna untuk mengidentifikasi distribusi lemak. ${ }^{8,9}$ Lingkar pinggang berkorelasi baik dengan IMT dan total lemak tubuh, serta berhubungan dengan risiko penyakit kardiovaskular. ${ }^{6}$ Penelitian Higgins dkk menunjukkan bahwa lingkar pinggang $71 \mathrm{~cm}$ pada anak prepubertal Afrika Amerika dan kulit putih lakilaki maupun perempuan merupakan prediktor faktor risiko penyakit kardiovaskular. ${ }^{10}$

Penelitian prevalensi obesitas dan komplikasinya pada anak usia sekolah dasar di Surakarta belum pernah dilakukan. Penelitian ini merupakan bagian dari penelitian payung yang akan mencari prevalensi obesitas dan komplikasinya pada anak usia sekolah dasar di Surakarta. Peneliti akan mencari ukuran lingkar pinggang yang merupakan prediktor faktor risiko penyakit kardiovaskuler pada anak obes di Surakarta.

\section{Metode}

Penelitian potong lintang dilakukan di Surakarta antara Desember 2004 - Januari 2005 dengan populasi terjangkau anak obes usia sekolah dasar kelas 1-6 di Surakarta. Pemilihan sampel dilakukan dengan cara melakukan pendataan jumlah semua Sekolah Dasar (SD) yang dilakukan di tiaptiap Kecamatan di Kota Surakarta. Randomisasi dilakukan pada tiap-tiap Kecamatan, diambil 20\% dari seluruh SD Negeri pada tiap-tiap kecamatan. Guru yang sudah dilatih dari semua SD yang terpilih kemudian mengambil semua anak yang tanpa cacat dengan Indeks Masa Tubuh (IMT) P85 (persentil 85). Anak-anak tersebut kemudian diseleksi oleh tim dokter untuk menentukan obesitas berdasarkan

Tabel 1. Karakteristik demografi $(\mathrm{n}=121)$

\begin{tabular}{lcc}
\hline Variabel & Rentang & Rata-rata $(\mathrm{SB})$ \\
\hline Umur (tahun) & $5-14$ & $9,2(1,9)$ \\
Tinggi badan $(\mathrm{cm})$ & $115-170$ & $136,5(10,7)$ \\
Berat badan $(\mathrm{kg})$ & $26-98$ & $49,9(12,9)$ \\
IMT $(\mathrm{kg} / \mathrm{m} 2)$ & $18,7-38,5$ & $26,3(3,4)$ \\
Lingkar pinggang (cm) & $60-110$ & $78,3(8,1)$ \\
Tekanan darah sistolik & $80-140$ & $108,2(11,9)$ \\
Tekanan darah diastolik & $30-90$ & $67,7(10,5)$ \\
Kolesterol $(\mathrm{mg} / \mathrm{dl})$ & $103-246$ & $166,3(27,1)$ \\
LDL kolesterol $(\mathrm{mg} / \mathrm{dl})$ & $52,4-183,7$ & $106,5(24,1)$ \\
HDL kolesterol $(\mathrm{mg} / \mathrm{dl})$ & $26-59$ & $41,6(7,8)$ \\
Trigliserid $(\mathrm{mg} / \mathrm{dl})$ & $23-551$ & $125,5(75,9)$ \\
\hline
\end{tabular}

Tabel 2. Persentase abnormal kadar lipid serum dan tekanan darah

\begin{tabular}{lcc}
\hline Kadar Lipid dan tekanan darah & $\mathrm{n}$ & $\%$ \\
\hline Kolesterol $(200 \mathrm{mg} / \mathrm{dl})$ & 14 & 11,6 \\
LDL kolesterol $(130 \mathrm{mg} / \mathrm{dl})$ & 19 & 15,7 \\
HDL kolesterol $(35 \mathrm{mg} / \mathrm{dl})$ & 24 & 19,8 \\
Trigliserid & 55 & 45,5 \\
$\quad(<10$ tahun $: 100 \mathrm{mg} / \mathrm{dl}$ & & \\
$\quad 10$ tahun $: 130 \mathrm{mg} / \mathrm{dl})$ & & \\
Tekanan darah sistolik & 6 & 5 \\
Tekanan darah diastolik & 18 & 14,9 \\
\hline
\end{tabular}


IMT P95. Selanjutnya anak-anak dengan obesitas yang memenuhi kriteria inklusi diikutkan dalam penelitian. Kriteria inklusi adalah orang tua telah menandatangani persetujuan mengikuti penelitian, tidak cacat, dan tidak terdapat tumor abdomen. Kriteria eksklusi adalah warga negara Indonesia keturunan dan mereka yang tidak datang ke laboratorium Prodia untuk pengambilan darah.

Data dianalisis dengan program SPSS 10.05. Lingkar pinggang dalam skala nominal ditentukan dengan cara menilai lingkar pinggang menjadi kelompok berdasarkan P50. Analisis regresi univariat dan multivariat risiko penyakit kardiovaskular (kolesterol total $200 \mathrm{mg} / \mathrm{dl}$, LDL kolesterol 130 $\mathrm{mg} / \mathrm{dl}, \mathrm{HDL}<35 \mathrm{mg} / \mathrm{dl}$ trigliserid $100 \mathrm{mg} / \mathrm{dl}$ untuk usia $<10$ tahun dan $130 \mathrm{mg} / \mathrm{dl}$ untuk usia lebih dari 10 tahun, tekanan darah sistolik tinggi dan diastol tinggi) dilakukan terhadap faktor-faktor yang diduga mempengaruhinya yaitu lingkar pinggang, jenis kelamin, pendidikan ibu, pendidikan ayah, genetik. Hasil ditampilkan dalam odds ratio (OR) dan 95\% convidence interval.

\section{Hasil}

Didapatkan 121 subjek memenuhi kriteria penelitian. Jenis kelamin laki-laki lebih banyak dari pada jenis kelamin perempuan. Karakteristik demografi tertera pada Tabel 1 .

Persentase abnormal kadar lipid serum tertera pada Tabel 2. Prevalensi kadar lipid abnormal yang ditunjukkan dengan peningkatan kadar trigliserid didapatkan pada hampir setengah dari jumlah anak yang obesitas. Tekanan darah sistolik dan diastolik lebih dari normal berdasarkan usia berturut-turut adalah 5\% dan 14,9\%.

Hasil analisis univariat faktor-faktor yang berpengaruh terhadap risiko penyakit kardiovaskular tertera pada Tabel 3. Tampak OR terbesar adalah pengaruh lingkar pinggang terhadap tekanan darah sistolik abnomal dan adanya riwayat genetik terhadap tekanan darah diastol abnomal, namun hasil tersebut secara statistik tidak signifikan. Hasil yang secara statistik signifikan didapatkan pada faktor jenis kelamin perempuan terhadap tekanan darah diastol abnomal dengan nilai OR kurang dari 1 .

Tabel 3. Analisis univariat faktor-faktor yang berpengaruh terhadap risiko penyakit kardiovaskular

\begin{tabular}{|c|c|c|c|c|c|c|}
\hline \multirow[t]{2}{*}{ Variabel } & \multicolumn{2}{|c|}{ Tekanan darah abnormal } & \multicolumn{4}{|c|}{ Dislipidemia } \\
\hline & Sistolik & Diastolik & Kolesterol & LDL & HDL & Trigliserid \\
\hline lingkar pinggang $\geq 77,5 \mathrm{~cm}$ & $4,7(0,5-41,8)$ & $1,9(0,7-5,6)$ & $1,0(0,3-3,3)$ & $1,6(0,6-4,5)$ & $1,1(0,4-2,6)$ & $0,9(0,5-2,0)$ \\
\hline Genetik & $1,6(0,2-14,4)$ & $6,3(0,8-14,4)$ & $1,1(0,3-4,1)$ & $0,9(0,3-2,6)$ & $1,7(0,5-5,6)$ & $1,0(0,4-2,4)$ \\
\hline Usia $>11$ tahun & $1,4(0,2-7,8)$ & $0,5(0,1-1,8)$ & $1,2(0,3-4,2)$ & $1,7(0,6-4,8)$ & $0,6(0,2-1,9)$ & $0,6(0,3-1,4)$ \\
\hline Jenis kelamin & $0,0(0,0-1,7 \mathrm{E}+32)$ & $0,0(0,0-0,7)^{* *}$ & $0,5(0,1-2,1)$ & $0,5(0,1-1,5)$ & $0,6(0,2-1,6)$ & $0,9(0,4-1,9)$ \\
\hline Pendidikan ayah & $1,4(0,2-7,8)$ & $1,8(0,6-5,4)$ & $0,8(0,2-2,8)$ & $0,8(0,3-2,4)$ & $1,2(0,5-3,2)$ & $0,9(0,5-2,1)$ \\
\hline Pendidikan ibu & $0,9(0,2-4,7)$ & $1,2(0,4-3,5)$ & $2,7(0,7-10,6)$ & $1,6(0,5-4,8)$ & $1,4(0,5-3,6)$ & $1,4(0,7-2,9)$ \\
\hline
\end{tabular}

** $\mathrm{p}<0,05$

Tabel 4. Analisis multivariat faktor-faktor yang berpengaruh terhadap risiko penyakit kardiovaskular

\begin{tabular}{|c|c|c|c|c|c|c|}
\hline \multirow[t]{2}{*}{ Variabel } & \multicolumn{2}{|c|}{ Tekanan darah abnormal } & \multicolumn{4}{|c|}{ Dislipidemia } \\
\hline & Sistolik & Diastolik & Kolesterol & LDL & HDL & Trigliserid \\
\hline lingkar pinggang $\geq 77,5 \mathrm{~cm}$ & $3,7(0,4-38,5)$ & $4,4(1,1-17,7)^{* *}$ & $1,3(0,4-6$ & $1,7(0,4-6,5)$ & $1,1(0,4-3,2)$ & $1,2(0,5-3,1)$ \\
\hline Genetik & $0,4(0,0-3,8)$ & $0,1(0,0-0,8)^{* *}$ & $0,9(0,2-4,4)$ & $1,1(0,3-3,8)$ & $0,6(0,2-1,9)$ & $0,9(0,4-2,3)$ \\
\hline Usia $>11$ tahun & $0,7(0,1-4,7)$ & $0,2(0,0-1,2)$ & $1,8(0,4-8,3)$ & $1,4(0,4-5,1)$ & $0,7(0,2-2,4)$ & $0,6(0,2-1,6)$ \\
\hline Jenis kelamin & $0,0(0,0-2,0 \mathrm{E}+32)$ & $0,1(0,0-1,0)$ & $0,7(0,2-3,4)$ & $0,7(0,2-2,5)$ & $0,5(0,1-1,5)$ & $1,0(0,4-2,4)$ \\
\hline Pendidikan ayah & $1,6(0,2-14,2)$ & $2,2(0,5-10,7)$ & $0,2(0,0-1,1)$ & $0,4(0,1-1,8)$ & $1,0(0,3-3,7)$ & $0,9(0,3-2,5)$ \\
\hline Pendidikan ibu & $0,6(0,1-4,7)$ & $0,6(0,1-2,9)$ & $8,7(1,3-59,8)^{* *}$ & $3,2(0,7-15,0)$ & $1,3(0,3-4,6)$ & $1,4(0,5-3,8)$ \\
\hline
\end{tabular}

${ }^{* *} \mathrm{p}<0,05$ 
Hasil analisis multivariat dengan memperhitungkan faktor lingkar pinggang, usia, genetik, pendidikan ayah, pendidikan ibu dan jenis kelamin terhadap masing-masing risiko penyakit kardiovaskular tertera pada Tabel 4. Hasil analisis multivariat yang secara statistik tetap tidak signifikan ditemukan pada lingkar pinggang terhadap tekanan darah sistolik abnomal, sedangkan genetik terhadap tekanan darah diastolik abnomal dengan OR kurang dari 1 secara statistik signifikan. Lingkar pinggang $\geq 77,5 \mathrm{~cm}$ menunjukkan hasil 4 kalinya mempunyai risiko untuk mendapatkan tekanan darah diastolik abnormal yang secara statistik signifikan. Hasil lain yang signifikan adalah pendidikan ibu terhadap kadar kolesterol $200 \mathrm{mg} / \mathrm{dL}$. Pengaruh lingkar pinggang terhadap risiko lain didapatkan OR antara 1,1 sampai dengan 3,7 tetapi secara statisik tidak signifikan.

\section{Diskusi}

Penelitian di Surakarta mendapatkan anak obes usia sekolah dasar memiliki rata-rata lingkar pinggang yang lebih besar dibandingkan penelitian pada 818 anak prapubertal di Italia. ${ }^{7}$ Perbedaan tersebut dapat diterangkan oleh perbedaan ras dan aktifitas fisik. Duncan $\mathrm{dkk}^{11}$ melakukan penelitian di Birmingham dengan 782 subjek, 467 kulit putih, 161 kulit hitam dan 154 Asia mendapatkan persentase lemak tubuh tertinggi pada etnis Asia. Aktifitas fisik yang rendah berpengaruh terhadap rata-rata IMT dan lingkar pinggang yang lebih besar. Davison dan Birch yang dikutip dari sumber yang sama menyatakan aktivitas fisik yang tinggi dapat mengkompensasi kelebihan kalori dari lemak sehingga menjaga berat badan yang sehat. Goran menambahkan aktivitas fisik yang rendah akan meningkatkan massa lemak dan persen lemak tubuh. Woodfield dkk. ${ }^{11}$ mendapatkan aktifitas fisik anak-anak ras Asia rendah. Mereka melaporkan partisipasi anak-anak Asia kurang lebih $2 \mathrm{kkal} / \mathrm{kg} / \mathrm{hari}$ lebih rendah (setara dengan aktifitas harian sedang selama 30 menit) dibandingkan anak-anak kulit putih, dan dibandingkan dengan kulit hitam $1 \mathrm{kkal} / \mathrm{kg} / \mathrm{hari}$ lebih rendah (setara dengan aktifitas sedang harian selama 15 menit). Lebih lanjut dikatakan anak-anak Asia memiliki persentase klasifikasi inaktif tertinggi $(52.6 \%)$ dibandingkan dengan kulit putih $(33.5 \%)$ dan kulit hitam $(38.5 \%)$.
Prevalensi dislipidemia terbanyak adalah kadar trigliserid diatas normal $45,5 \%$, tetapi rata-rata kadar kolesterol total dan LDL kolesterol lebih baik dibandingkan dengan penelitian oleh Maffeis dkkl. ${ }^{7} \mathrm{Hal}$ tersebut dapat diterangkan karena perbedaan asupan lemak. Asupan lemak akan mempengaruhi profil lipid darah. Pada Lind T dkk dikatakan bahwa penduduk Jawa Tengah khususnya Purworejo mengkomsumsi rendah protein hewani. ${ }^{12}$

Prevalensi tekanan darah tinggi baik sistolik maupun diastolik berturut-turut sebesar 5\% dan 14,9\%. Tekanan darah dipengaruhi oleh beberapa faktor antara lain usia, tinggi badan, berat badan, obesitas, asupan garam, aktifitas fisik dan maturasi seksual. ${ }^{13,14,15}$ Penelitian Bogalusa Heart Study pada populasi birasial (1/3 kulit hitam) mendapatkan prevalensi baik tekanan darah sistolik tinggi maupun diastolik tinggi pada anak-anak usia 5 sampai 17 tahun adalah sebesar 5\%. ${ }^{16}$ Penelitian ini tidak memperhitungkan pengaruh maturasi seksual, tinggi badan maupun berat badan terhadap tekanan darah. Usia dikatagorikan 11 tahun sebagai risiko tinggi berdasarkan definisi early adolescence dimulai usia 11 tahun. Tidak didapatkan hasil yang signifikan pengaruh faktor usia terhadap tekanan darah sistolik tinggi dan diastolik tinggi baik pada analisis secara univariat maupun pada analisis multivariat. Hal tersebut masih mungkin dipengaruhi oleh perbedaan maturasi seksual, aktifitas fisik, asupan garam yang tidak diperhitungkan dalam penelitian ini.

Lingkar pinggang dapat berubah selama pertumbuhan dan maturasi normal, ${ }^{17}$ cut of point yang spesifik usia diperlukan untuk mengklasifikasikan status adiposity diantara anak-anak dan dewasa. Di Indonesia belum didapatkan data cut of point lingkar pinggang tersebut. Peneliti menggunakan P50 (lingkar pinggang $77,5 \mathrm{~cm}$ ) untuk mengkatagorikan kelompok dengan faktor risiko penyakit kardiovaskular. Dengan menggunakan ukuran tersebut didapatkan $64 \%$ anak termasuk dalam lingkar pinggang tinggi $(77,5 \mathrm{~cm})$. Hasil analisis menunjukkan bahwa lingkar pinggang $77,5 \mathrm{~cm}$ dapat digunakan untuk memprediksi risiko penyakit kardiovaskular. Hal itu ditunjukkan dengan kemungkinan 4,4 kali anak obes usia sekolah dasar mempunyai tekanan darah diastolik tinggi; 3,7 kali mempunyai tekanan darah sistolik tinggi dan 1,7 kali mempunyai kadar LDL abnormal. Hasil ini mendukung penelitian-penelitian sebelumnya yang menyimpulkan lingkar pinggang dapat digunakan sebagai prediktor faktor risiko. Penelitian Jansen dkk menggunakan 2597 subjek kulit hitam dan kulit 
putih, berusia 5 tahun sampai 18 tahun. Penelitian ini membandingkan pengaruh kombinasi IMT dan lingkar pinggang terhadap faktor risiko penyakit arteri koroner. Jansen ${ }^{17}$ mendapatkan OR 2,05 (95\% interval kepercayaan 1,30;3,24) untuk rendahnya kadar HDL kolesterol pada kelompok obes dengan lingkar pinggang yang tinggi dan OR 1,91 (95\% interval kepercayaan $1,25 ; 2,97)$ untuk mendapatkan kadar trigliserid tinggi. Hasil yang lain yaitu LDL tinggi, tekanan darah tinggi, HDL rendah, glukosa darah tinggi, insulin tinggi dan sindroma metabolik didapatkan tidak bermakna. Berbeda dengan penelitian ini yang menggunakan cut of point lingkar pinggang $77,5 \mathrm{~cm}$, Jansen $\mathrm{dkk}^{17}$ menggunakan cut of point lingkar pinggang yang lebih besar yaitu $92,5 \pm 12,1 \mathrm{~cm}$. Lingkar pinggang merupakan prediktor yang kuat terhadap visceral fat sesudah dilakukan kontrol terhadap IMT. ${ }^{18}$ dan didapatkan visceral fat merupakan prediktor faktor risiko penyakit arteri koroner diantara anak-anak dan dewasa. ${ }^{19}$ Peningkatan OR risiko penyakit kardiovaskuler pada kelompok lingkar pinggang tinggi pada penelitian ini dapat diterangkan kemungkinan karena tingginya visceral fat.

Kelemahan penelitian ini, tidak disingkirkan penyebab hipertensi seperti penyakit ginjal dan penyakit jantung sehingga selain obesitas hasil penelitian ini masih mungkin dipengaruhi faktor tersebut. Keterbatasan desain penelitian menggunakan potong lintang kurang mengidentifikasi risiko penyakit kardiovaskular. Desain penelitian dengan menggunakan data longitudinal diperlukan untuk memberikan bukti yang lebih kuat terhadap nilai prediksi dari lingkar pinggang.

\section{Kesimpulan}

Prevalensi penyakit kardiovaskular yang ditunjukkan oleh ketidaknormalan hasil trigliserid pada anak obes di Surakarta adalah sebesar 45,5\%. Lingkar pinggang lebih besar atau sama dengan $77,5 \mathrm{~cm}$ mungkin dapat dipertimbangkan sebagai prediktor risiko penyakit kardiovaskular pada anak obes usia sekolah dasar. Anak obes usia sekolah dasar yang memilik lingkar pinggang $77,5 \mathrm{~cm}$ mempunyai kemungkinan 4,4 kali mengalami tekanan darah diastolik tinggi; 3,7 kali mengalami tekanan darah sistolik tinggi dan 1,7 kali mengalami kadar LDL abnormal. Pengukuran lingkar pinggang disarankan menjadi pemeriksaan rutin pada anak dengan obesitas untuk mencari risiko penyakit kardiovaskular. Penelitian-penelitian mendatang dengan menggunakan desain longitudinal diperlukan untuk memastikan hubungan temporal antara lingkar pinggang dengan penyakit kardiovaskular.

\section{Ucapan terimakasih}

Peneliti mengucapkan terimakasih kepada DIKPORA Surakarta, para guru di seluruh SD yang terlibat di dalam penelitian ini, anak-anak dan orang tuanya yang telah dengan ikhlas dan tulus membantu penelitian ini. Terima kasih kami sampaikan kepada Lab Prodia yang telah memberikan sumbangan tenaga dan pemeriksaan darah untuk berlangsungnya penelitian ini. Terimakasih kepada Dr. Damayanti Rusli Sjarif, PhD, SpA(K) selaku ketua penelitian multisenter obesitas anak di Indonesia.

\section{Daftar Pustaka}

1. Reilly JJ, Wilson ML, Summerbell CD, Wilson DC. Obesity: diagnosis, and treatment; evidence based answer to common questions. Arch Dis Child 2002;86:392-5.

2. Deckelbaum R.J, Williams CL Childhood obesity : the health issue. Obes Res 2001; 9:239S-43S.

3. Nasar, S.S. Obesitas pada anak. Aspek klinis dan pencegahan. Dalam Naskah lengkap PKB-IKA XXXV. Masalah gizi ganda dan tumbuh kembang anak. Jakarta: Bina Rupa Aksara 1995.

4. Nammi S, Koka S, Chinnala KM, Boini KM. Obesity : an overview on its current perspective and treatment options. Didapat dari http://www.nutritionj.com/content/3/1/3. Diakses Desember 2004.

5. Barlow SE, Dietz WH. Obesity evaluation and treatment: expert committee recommendations. Pediatrics 1998;102:1-11

6. Zhu S, Wang Z, Heshka S. Waist circumference and obesity-assosiacet risk factor among whites in third national health and nutrition examinatin survey: clinical actin thresholds. Am J Clin Nutr 2002;76:743-9.

7. Maffeis C, Pietrobelli A, Grezzani A, Pravera S, Tato L. Waist circumference and cardiovascular risk factors in prepubertalchild. Obes Res 2001;9:179-87.

8. Wang J. Waist circumference: a simple, inexpensive, and reliable tool that should be included as part of physical examinations in the doctor's. Am J Clin 2003;78:902-3.

9. Daniels SR, Khoury PR, Marrison JA. Utility of differ- 
ent measures of body fat distribution in children and adolescents. Am J Epidemiol 2000;152:1179-84.

10. Higgins PB, Gower BA, Hunter GR, Goran MI. Defining health-related obesity in prepubertal children. Obes Res 2001; 9:233-40.

11. Duncan MJ, Woodfield L, Al-Nakeeb Y. Differences body fat of british children from various ethnic groups. European physical education review 2004;10:41-52.

12. Lind T, Lonnerdal B, Stenlund H. A community-based randomized controlled trial of iron and zinc supplementation in Indonesia infants: effects on growth and development. Am J Clin Nutr 2004;80:729-36.

13. Daniels SR, McMahon RP, Obarzanek E. Longitudinal of change in blood pressure in adolescent girls. Hypertension 1998;31:97-103.

14. Fraser GE, Phillips RL, Harris R. Physical fitness and blood pressure in school children. Circulation 1983; 67:405-10.

15. Sack FM, Svetkey LP, Vollmer WM. Effect on blood pressure of reduction dietary sodium and the dietary approacjes to stop hypertension (DASH) diet. N Engl J Med 2001;344:3-10.

16. Freedman DS, Srinivasan SR, Dietz W, Berenson GS. The relation of overweight to cardiovasculair risk factors among children and adolescent: the Bogalusa Heart Study. Pediatrics 1999; 103:1175-82.

17. Jansen I, Katzmarzyk PT, Srinivasan SR. Combined influence of body mass index and waist circumference on coronary artery disease risk factors among children and adolescents. Pediatrics 2005; 115:1623-30.

18. Gower BA, Goran MI, Treuth, MT, Nagy TR. Prediction of intra-abdominal and subcutaneous abdominal adipose tissue in healthy prepubertal children. Int J Obes Relat Metab Disord 1998;22:549-58.

19. Goran MI, Gower BA. Relation between visceral fat and disease risk in children and adolescent. Am J Clin Nutr 1999;70(supll):149s-56s. 